\title{
PPSM 2016
}

ARTICLES

\section{THE CONSTITUTIVE INSTRUMENTS OF THE INTERNATIONALIZATION OF HUMAN RIGHTS}

Keywords: the United Nations, the United Nations Charter, the International Court of Justice, the Universal Declaration of Human Rights.

1. On 26 April 1945, the United Nations (UN) founding convention was held in San Francisco ${ }^{2}$. As a result of its deliberations, the United Nations Charter (UN Charter) gained its final form ${ }^{3}$.

The UN Charter is generally considered a special treaty. Being a treaty that constitutes the $\mathrm{UN}^{4}$, it is perceived both as "the fundamental anchoring

1 The Department of Human Rights Protection and International Humanitarian Law, the Institute of International Law, European Union and International Relations, the Law and Administration Faculty, The Cardinal Stefan Wyszynski University.

2 Originally 46 states participated in it, with four more joining later. Poland was not among these states. Only after the establishment of the Provisional Government of National Unity was Poland allowed to participate in the United Nations as a primary member.

3 The shape of the UN and its rules of procedure were, in principle, determined at a working conference in the summer of 1944, in Dumbarton Oaks, attended by representatives of the then-four great powers: the Soviet Union, the United States, the United Kingdom and China. Cf. T. Łoś-Nowak, Organizacje w stosunkach międzynarodowych, Wydawnictwo UWr, Wrocław 1997, pp. 82-83.

${ }^{4}$ It entered into force on 24 October 1945. This day is now celebrated globally as United Nations Day. The United Nations General Assembly first gathered in London on 10 January 1946. 
of the obligations of the States in the sphere of international law, and as such is recognized as an international quasi-constitution"5. Meanwhile, the human rights clauses contained in the UN Charter set the stage in the process of institutionalizing human rights within international law ${ }^{6}$ and, consequently, establishing a new branch of international law, i.e. international human rights law ${ }^{7}$. These provisions are contained in the Preamble as well as in the six subsequent Articles of the Charter.

In the Preamble, the UN Member States declared their readiness to reaffirm faith "in fundamental human rights, in the dignity and worth of the human person, in the equal rights of men and women and of nations large and small", and further determined they would "promote social progress and better standards of life in larger freedom". The above provisions, as one of the foundations of the axiology of modern international law, were adopted under certain historical conditions, whose specifics were rendered exceptionally aptly by John P. Humphrey, who stated that:

„The traumatic experiences through which the world had just passed, including the studied violation of basic rights by the government of one of the most civilized countries, provided the catalyst to revolutionize traditional concepts of the relation of international law to individuals. The Second World War and the events preceding it set forces in motion that radically changed the content and very nature of international law. Traditional international law, ius inter gentes, which had governed only the relations of states, was to become a new kind of legal order for which the old name was no longer appropriate. International law became world law"8.

5 T. Jasudowicz, Kodyfikacja międzynarodowej ochrony praw człowieka, [in:] B. Gronowska, T. Jasudowicz, M. Balcerzak, M. Lubiszewski, R. Mizerski (eds.), Prawa człowieka i ich ochrona, Wydawnictwo TNOiK, Toruń 2005, p. 49.

${ }^{6}$ Cf. generally D.W. Bowell, The Law of International Institutions, Manchester University Press, Manchester 1982; E. Lauterpacht (ed.), International Law, Being the Collected of Hersch Lauterpacht, Vol. 3, Cambridge University Press, Cambridge 1977, pp. 145-220.

7 Cf. N. Rodley, International Human Rights Law, [in:] M. D. Evans (ed.), International Law, Oxford University Press, Oxford 2014, p. 789; M. O’Boyle, M. Lafferty, General Principles and Constitutions as Sources of Human Rights Law, [in:] D. Shelton (ed.), The Oxford Handbook of International Human Rights Law, Oxford University Press, Oxford 2013, p. 195; D. Shelton, Introduction, [in:] D. Shelton (ed.), The Oxford Handbook of International Human Rights Law, Oxford University Press, Oxford 2013, p. 1.

8 J. P. Humphrey, The International Bill of Rights: Scope and Implementation, „William \& Mary Law Review" 17 (1976), p. 527. 
$\because: \because:$ E. H. Morawska, The constitutive instruments...

In the dramatic experience with Nazi totalitarianism, there is an answer to why the States recognized the need for a common response in terms of universal human rights in light of "Nazism, which revealed the horror that could arise from the positivist understanding of the law in which man does not mean anything"9. It seems that only in such special circumstances was such a reaction of states possible ${ }^{10}$. International law had been then defined as the law governing exclusively relations between nations-states ${ }^{11}$. Hersch Lauterpacht clearly argued that "the orthodox positivist doctrine states explicitly that only states are subjects of international law"12. Individuals were considered more as objects, rather than subjects of that law, to the extent that states had no direct obligations toward them under international law since those commitments were obligations to the states whose citizens those individuals were ${ }^{13}$.

The following human rights clauses of the Charter are contained in Art. 1, which defines the goals to be achieved by the international community through the UN. Among these purposes is to bring about international cooperation in developing and promoting respect for human rights and fundamental freedoms for all, without distinction as to race, sex, language, or religion (Art. 1(3) of the UN Charter) ${ }^{14}$. Thus, the promotion of respect for

9 J. J. Shestack, The Jurisprudence of Human Rights, [in:] T. Meron (ed.), Human Rights in International Law Legal and Policy, Oxford University Press, Oxford 1984, p. 86.

10 "the high rank of human rights in the UN Charter is not only the success of the US diplomacy, but also the evidence of the growing influence of civil society on global issues" - M. A. Glendon, A World Made New. Eleanor Roosevelt and the Universal Declaration of Human Rights, New York 2001, p. 10. The San Francisco Conference was attended - as consultants and observers - by more than 40 non-governmental organizations, mostly from the United States. They had a big impact on support in "the issue of human rights". Cf. W. Osiatyński, Prawa człowieka i ich granice, Wydawnictwo Znak, Krakw 2011, p. 44. Also mentioned by J. P. Humphrey, The International Bill of Rights, pp. 527-528. Similarly N. Rodley, op.cit., p. 786.

${ }^{11}$ Cf. W. Góralczyk's remarks in: Prawo międzynarodowe publiczne w zarysie, PWN Warszawa 1989, p. 8. What stands out here is the inclusion of the "protection of human groups and human rights" in the issue of "state population".

12 E. Lauterpacht (ed.), op.cit., p. 489. Similarly, albeit slighly milder: C. Mik, Charakter, struktura i zakres zobowiązań z Europejskiej Konwencji Praw Człowieka, „Państwo i Prawo" (1992), Issue 4, p. 5.

13 L. Oppenheim, International Law: A Treaties, Vol. 1, Longmans, London 1912, p. 362,

14 The words "based on respect for the principle of equality and self-determination of nations" in Art. 1(2) and "in promoting and encouraging respect for human rights 
human rights was placed among the purposes whose, as Roman Kwiecien puts it, "can be interpreted as the highest value of the international legal order" 15 .

The open question, however, is whether the purpose in question is of the same value as the maintenance of international peace and security, or whether it expresses a fundamental, absolute value, although the highest value is the "universal peace" provided for in Art. 1(2) of the UN Charter ${ }^{16}$. It seems, none the less, that it is more accurate to speak in this case of the organic and thus unbreakable unity of the UN purposes, the reason for which the denial of human dignity and freedom anywhere is a threat to peace and security everywhere ${ }^{17}$. This understanding of the UN purposes is also urged by the judge of the International Court of Justice (I.C.J.), Kōtarō Tanaka, who noted that "the repeated references in the Charter to fundamental rights and freedoms (...) appear to be one of its differences in relation to the pact of the League of Nations, in which the close link between peace and respect for human rights was not as strongly emphasized as in the Charter of the United Nations"18.

and for fundamental freedoms for all without distinction as to race, sex, language, or religion" were not provided for in the Dumbarton Oaks Files, but they were introduced in San Francisco.

15 R. Kwiecień, Między zakazem używania siły zbrojnej a nakazem poszanowania praw człowieka. W poszukiwaniu głównych wartości współczesnego prawa międzynarodowego, [in:] E. Karska (ed.), Globalne problemy ochrony praw człowieka, Wydawnictwo UKSW, Warszawa 2015, p. 73.

${ }^{16}$ R. Kwiecień, op.cit., p. 73 et seq.; T. Jasudowicz, Zakaz użycia lub groźby użycia siły „w jakikolwiek inny sposób niezgodny z celami Narodów Zjednoczonych”, [in:] T. Jasudowicz, M. Balcerzak, J. Kapelańska-Pręgowska (eds.), Współczesne problemy praw człowieka i międzynarodowego prawa humanitarnego, Wydawnictwo TNOiK, Toruń 2009, p. 115 et seq.

17 In a similar vein, T. Jasudowicz, $W$ poszukiwaniu podstawowych wartości międzynarodowego porzadku prawnego. Polemika z poglądami prof. Romana Kwietnia, [in:] E. Karska (ed.), Globalne problemy, pp. 78-85. Regarding the doctrine's position on the complex relationship between the principles of the UN Charter mentioned in Art. 2 see Z. Resich's remarks and the visibility of the principle of non-interference. Id. Międzynarodowa ochrona praw człowieka, PWN, Warszawa 1981, pp. 32-36.

${ }^{18}$ Cf. Dissenting opinion the I.C.J. judge Kōtarō Tanaka to the judgment of the J.C.J. ruled in South West Africa Cases (Ethiopia v. South Africa; Liberia v. South Africa), dated 18 July 1966, p. 289, I.C.J. Reports 1966, p. 6. 
$\because: \because:$ E. H. Morawska, The constitutive instruments...

The above references to human rights should be read as undermining the concept of individual rights as the laws of sovereign states ${ }^{19}$. With that being said, neither the provisions of the Preamble nor Art. 1 of the UN Charter were developed into a catalog of concrete human rights and freedoms ${ }^{20}$. In fact, the UN Charter indicates only two rights, i.e. the right to self-determination of peoples ${ }^{21}$ and the prohibition of discrimination ${ }^{22}$.

On the other hand, the human rights clauses contained in the Preamble and Art. 1(3) of the UN Charter were developed in the specific competence of the UN principal bodies, namely the UN General Assembly (UN GA) and the UN Economic and Social Council (ECOSOC), as well as in the Member States' commitment to joint or separate action (Art. 56 of the UN Charter) in the implementation of the tasks and objectives set out in Art. 55 of the UN Charter.

As far as the UN bodies are concerned, in the light of the UN GA Charter, the UN are entitled to initiate studies and recommendations in order to "achieve international cooperation in solving international problems of an economic, social, cultural, or humanitarian character, and in promoting and encouraging respect for human rights and for fundamental freedoms for all without distinction as to race, sex, language, or religion" (Art. 13(1) (b) of the UN Charter). Similar powers were entrusted to the ECOSOC, allowing it, among other things, to "make recommendations for the purpose of promoting respect for, and observance of, human rights and fundamen-

19 M. S. McDougal, G. Bebr, Human Rights in the United Nations, "American Journal of International Law" 58 (1964), pp. 603-641.

${ }^{20}$ For these reasons the UN Charter is not recognized as a benchmark for specific cases. In the view of the UN Commission on Human Rights whose human rights clauses are abstract principles that are difficult to apply in specific cases, which in effect prevents (adequate) response to allegations of infringement. Cf. P.E. Jacob, A. L. Atherton, The Dynamics of International Organization, Dorsey Press, Homewood 1965, p. 579.

${ }^{21}$ Cf. Preamble and Art. 1(2) of the UN Charter.

${ }^{22}$ See also Art. 73 Chapter XI: Declaration regarding non-self-governing territories and Art. 76 Chapter XII: International Trusteeship System. For more, see P. G. Lauren, First Principles of Racial Equality: History and the Politics and Diplomacy of Human Rights Provisions in the United Nations Charter, "Human Rights Quarterly" 5 (1983); A. Cassese, The General Assembly: Historical Perspective 1945-1989, [in:] P. Alston (ed.), The United Nations and Human Rights: A Critical Appraisal, Oxford University Press, Oxford 2004, p. 25. 
tal freedoms for all”23. It may further prepare convention designs and convene international conferences on matters falling within its competence ${ }^{24}$. The ECOSOC may also take appropriate measures so to receive regular reports from specialized organizations. Apart, it may conclude agreements with the UN Member States and the specialized organizations to receive reports on the measures taken to implement its own recommendations, or those of the UN GA falling within its competence. Art. 68 of the UN Charter, meanwhile, authorizes the ECOSOC to appoint, inter alia, human rights "commissions" 25 , with the most notable examples being the UN Commission on Human Rights ${ }^{26}$, the UN Commission on the Status of Women ${ }^{27}$ and the Sub-Commission on the Prevention of Discrimination and the Protection of Minorities ${ }^{28}$.

It should be borne in mind, however, that although the UN Charter has made the UN bodies responsible for promoting human rights and fundamental freedoms, it has given them relatively small powers in terms of the ability to enforce and respect its purposes and principles ${ }^{29}$. While it is true that all Member States have undertaken to pursue joint and independent actions, including the Organization, to achieve the objectives set out in Art. 55 of the UN Charter ${ }^{30}$, and therefore also for the universal respect and pres-

${ }^{23}$ Cf. Art. 62(2) of the UN Charter.

${ }^{24}$ Cf. Art. 62(3) and (4) of the UN Charter, respectively.

${ }^{25}$ It determines that the ECOSOC will set up commissions in the economic and social sphere and commissions that promote human rights, as well as any other commissions that may be required to fulfill its functions.

${ }^{26}$ Founded in 1946. However, pursuant to Resolution 60/251 of 3 April 2006, the UN GA appointed the Human Rights Council in its place.

27 Founded in 1946.

${ }^{28}$ Founded in 1974 as an auxiliary body of the Commission on Human Rights

29 As aptly noted by Zbigniew M. Klepacki „According to the Charter, the UN does not become a transnational organization or a supranational government. The Charter also emphasizes that the United Nations has no right to intervene in the affairs of other nations because the Charter proclaims the principle of non-interference" - Z.M. Klepacki, Organizacja Narodów Zjednoczonych 1945-1985, Wydawnictwo Ciechanowskie Towarzystwo Naukowe, Ciechanów 1988, p. 78.

30 Art. 55 of the UN Charter states that „With a view to the creation of conditions of stability and well-being which are necessary for peaceful and friendly relations among nations based on respect for the principle of equal rights and self-determination of peoples, the United Nations shall promote: a. higher standards of living, full employment, and conditions of economic and social progress and development; b. solutions of inter- 
$\because: \because:$ E. H. Morawska, The constitutive instruments...

ervation of human rights and fundamental freedoms for all without distinction as to race, sex, language, or religion ${ }^{31}$, the literature has questioned whether the human rights clauses of the UN Charter, including the provisions of Art. 56, have legally binding commitments for the states. Manley 0 . Hudson, for instance, believed that "the Charter was limited to the definition of an action program for the United Nations, for the implementation of which the Members are obliged to cooperate" 32 . He then stated that:

„the interpretation in the light of which the relevant provisions of the Charter would impose on the Members of the United Nations the legally binding obligation to respect human rights and freedoms may act towards the disintegration of the Charter" 33 .

A similar position is shared by Hans Kelsen, who expresses the following view:

„The Charter does not impose upon the Members a strict obligation to grant to their subjects the rights and freedoms mentioned in the Preamble or in the text of the Charter. The language used by the Charter in this respect does not allow the interpretation that the Members are under legal obligations regarding the rights and freedoms of their subjects" ${ }^{\prime 2}$.

On the other hand, Lauterpacht argued that all Member States are legally obliged to act in accordance with the objectives of the UN Charter, and that these Members are legally obliged not only to encourage and promote the respect for human rights envisaged in the Charter but also to respect them.

national economic, social, health, and related problems; and international cultural and educational cooperation; and c. universal respect for, and observance of, human rights and fundamental freedoms for all without distinction as to race, sex, language, or religion".

${ }^{31}$ The significance of the provisions of the UN Charter for the international security of human rights was noted, among others, by: C. Ovey, R. C. A. White, F. G. Jacobs (ed.), Jacobs and White, The European Convention on Human Rights, Oxford University Press, Oxford 2006, p. 1.

${ }^{32}$ M. O. Hudson, Integrity of International Instruments, "American Journal of International Law" 42 (1948), pp. 105-107.

33 Ibidem

${ }^{34} \mathrm{H}$. Kalsen, Law of the United Nations. A Critical Analysis of Its Fundamental Problems, The Lawbook Exchange, New York 1950, pp. 29-30. 
All the more so since the provisions of Art. 56 of the UN Charter expressly contained the root of the legal obligation ${ }^{35}$. He stated that:

„Due to its purposes, the UN program is the heir to all great historical human rights movements (including the British, French and American revolutions and the events that they initiated), permanent elements inherent in the traditions of natural law and natural laws, and most religions and philosophies existing in the world, as well as the interconnections between the simple respect for human dignity and all other individual and community values"36.

It can be emphasized here that Art. 56 of the UN Charter states, expressis verbis, that all UN Members pledge (French: s'engagent/Russian: обязуются) to take joint and independent action in co-operation with the Organization to achieve the objectives set out in Art. 55 of the UN Charter, which covers - inter alia - universal respect for and observance of human rights and fundamental freedoms for all. In a certain way, each Member State is obliged to respect human and fundamental rights, not only of its own citizens, but of all people. According to Ian Brownlie, the provisions in question „as treaty provisions applicable to the Organization and its Members, these rules are of particular significance" ${ }^{37}$.

It seems, therefore, that Art. 55 and Art. 56 of the UN Charter binds Member States to respect and observe human rights and fundamental freedoms for all $^{38}$. This view finds support in the interpretation of these provisions offered by the I.C.J. It is because in the advisory opinion on Namibia of 1971, the I.C.J. stated that:

„the former mandated power has pledged to respect and observe, in an area of international status, human rights and fundamental freedoms of all without distinction as to race. Establishing and enforcing differences, exclusions, restric-

35 H. Lauterpacht, Sovereignty and Human Rights, [in:] E. Lauterpacht (ed.), op.cit., pp. 47-49, p. 417.

${ }^{36}$ As cited in M. S. McDougal, G. Bebr, op.cit., p. 604.

37 I. Brownlie, Principles of Public International Law Oxford University Press, Oxford 1973, p. 553.

${ }^{38}$ Also T. Jasudowicz, Prawa człowieka $w$ Karcie Narodów Zjednoczonych, [in:] B. Gronowska, T. Jasudowicz, M. Balcerzak, M. Lubiszewski, R. Mizerski (eds.), op.cit., pp. 47-52. 
:::: E. H. Morawska, The constitutive instruments...

tions and limitations solely on the basis of race, skin color, national or ethnic origin, which are a denial of fundamental human rights, is a gross violation of the purposes and principles of the Charter"39.

Although the above findings referred to the obligations of South Africa as a country having a mandate to manage the then territory of South-West Africa, it is stressed in the literature that there is no reason to limit them to this particular situation ${ }^{40}$. According to Egon Schwelb, the I.C.J.'s opinion states that the UN Charter requires all States to comply with at least the basic human rights catalog to which it refers, albeit without indicating them exhaustively ${ }^{41}$.

As aptly noted by Thomas Buergenthal, one of the most important implications of the inclusion of human rights clauses in the UN Charter was their internationalization ${ }^{42}$. This is related to the issue of redefinition of the principle of sovereignty of states ${ }^{43}$. Until now, international law was created by states but also with states in mind. The post-war process of redefinition of the sovereignty principle is of course broader and not limited to issues related to human rights ${ }^{44}$, but the international legal order has ceased to

${ }^{39}$ Cf. I. C. J. advisory opinion on Legal Consequences for States of the Continued Presence of South Africa in Namibia (South West Africa) notwithstanding Security Council Resolution 276 (1970) of 21 June 1971 r. item. 76, I. C. J. Reports 1971, p. 16, item. 57; Also I. Brownlie, Principles of International Law, Oxford University Press, Oxford 1990, p. 569; E. Schwelb, The International Court of Justice and Human Rights Clauses, „American Journal of International Law" 66 (1972), p. 337.

${ }^{40}$ M. N. Shaw, Prawo międzynarodowe, Wydawnictwo Książka i Wiedza, Warszawa 2008, p. 172; 0. De Schutter, International Human Rights Law, Cambridge University Press, Cambridge 2014 [2nd ed.] p. 49.

${ }^{41}$ E. Schwelb, The International Court of Justice, pp. 348-349; in this spirit, the provisions of the Vienna Declaration and the Program of Action of the World Conference on Human Rights in Vienna in 1993 (cf. item. 4 of the Preamble).

42 T. Buergenthal, International Human Rights, St. Paul, Minnesota USA 1988, p. 21.

${ }^{43}$ For more on the relationship between state sovereignty and human rights, see: F. Capotorti, Human Rights: the Hard Road Towards Universality, [in:] R. St. J. Mac Donald, D. M. Johnston (eds.), The Structure and Process of International Law: Essays in Legal Philosophy Doctrine and Theory, Martinus Nijhoff, Dordrecht-Bostron-Lancaster 1986, pp. 977-1000.

${ }^{44}$ Cf. L. Wildhaber, Sovereignty and International Law, [in:] R. St. J. MacDonald, D.M, Johnston, The Structure and Process of International Law: Essays in Legal Philosophy, Doctrine and Theory, Martinus Nijhoff, Dordrecht 1986, p. 442 et seq. 
be exclusively focused on the principle of sovereignty ${ }^{45}$. It was not so much about the incapacitation of the state, but rather about the obligation to take human rights into account in national law and practice, and to consistently submit this area for international supervision, even if in the least ${ }^{46}$.

It can therefore be said, as Anne Peters points out, there is a need to humanize the idea of sovereignty of states, as a result of which "the conflict between state sovereignty and human rights cannot be resolved on a balanced basis where sovereignty is faced against human rights on equal terms, but rather it should be resolved on the basis of a presumption for humanism" ${ }^{\text {"47 }}$. Obviously, this does not change the fact that states still are the „primary actors in international relations and international law and still perform central functions" ${ }^{\prime 48}$.

45 C. Tomuschat, International Law: Ensuring the Survival of Mankind on the Eve of a New Century: General Course on Public International Law, „Recueil des Cours, Collected Courses" (1999), Vol. 281, pp. 161-162.

${ }^{46}$ C. Mik, Charakter, p. 6. E.g. According to John Rawls, human rights should be understood as a class or category of law that limits the internal autonomy of the state. Human rights violations are considered as justification for external intervention - J. Rawls, Prawo ludów, Fundacja Aletheia,Warszawa 2001, p. 117. Joseph Raz, meanwhile, writes that „Sovereignty does not justify state action but protects the state against external interference. The violation of human rights makes [the state] lose this right" - J. Raz, Human Rights without Foundations, „Oxford Legal Studies Research Paper” 14 (2007), p. 10.

47 A. Peters, Humanity as the A and $\Omega$ of Sovereignty, "European Journal of International Law" 20 (2009), p. 514 „State sovereignty is not only - as in the meanwhile canonical view - limited by human rights, but is from the outset determined and qualified by humanity, and has a legal value only to the extent that it respects human rights, interests, and needs. It has thus been humanized. Consequently, conflicts between state sovereignty and human rights should not be approached in a balancing process in which the former is played off against the latter on an equal footing, but should be tackled on the basis of a presumption in favour of humanity". In similar spirit, B. Mielnik, Udziat pozapaństwowych podmiotów $w$ rozwoju prawa międzynarodowego, [in:] J. Kolasa, A. Kozłowski (eds.), Rozwój prawa międzynarodowego - jedność czy fragmentacja?, Wydawnictwo UWr, Wrocław 2007, pp. 62-63.

${ }^{48}$ V. Engström, Who is Responsible for Corporate Human Rights Violations?, Institute for Human Rights, Turku 2002, p. 14. 
$\because: \because:$ E. H. Morawska, The constitutive instruments...

2. Closing the conference in San Francisco, the US President Harry Truman noted that:

„We have good reasons to expect the framing of an international bill of rights, acceptable to all nations involved...The Charter is dedicated to the achievement and observance of human rights and fundamental freedoms. Unless we can attain those objectives for all men and women everywhere - without regard to race, language, or religion - we cannot have permanent peace and security"49.

Thus, he pointed out explicitly the next stage of the institutionalization of human rights in international law, i.e. the UN work on a document that would contain the catalog of basic human rights ${ }^{50}$. Works on this catalog were conducted at the forum of the Commission on Human Rights ${ }^{51}$. Initially, it was assumed that it would be included in a treaty legally binding the Member States ${ }^{52}$, but ultimately it was abandoned and, as we know today, the declaration adopted by the UN GA resolution was accepted instead ${ }^{53}$. That project was submitted to the General Assembly via the ECOSOC ${ }^{54}$ at the Paris meeting that lasted from 21 September to 12 December 1948.

49 As cited in A. H. Robertson, J. G. Merrills, Human rights in the World: An introduction to the study of the international protection of human rights, Manchester University Press, Manchester 1972, p. 25.

${ }^{50}$ During the conference, delegations from Chile, Cuba, Mexico and Panama requested the adoption of the "Declaration on the Essential Rights of Man". Nevertheless, it was considered that this would require a detailed analysis, for which there was then simply no time. Cf. information on the progress of the works on: http://www.ohchr.org/ Documents/Publications/FactSheet2Rev.1en.pdf (access: 4.6.2017).

${ }^{51}$ It was founded under Art. 68 of the UN Charter, although the article does not mention such mandate.

${ }^{52}$ Z. Resich, describing the first stage of the works, highlights that „In 1946, the ECOSOC founded the Preparatory Commission for Human Rights and called for the analysis of the already existing human rights projects. In this way, the projects of Panamá, Chile, Cuba, the American Federation of Labor and the projects by H. Lauterpacht and M. Alvarez were accounted for. (...) The result of the work was a raw material, which was merely a moral foundation. It was later adapted to the needs of the modern world and processed by lawyers. At that time the Commission on Human Rights was constituted, which, at its first session chaired by F. D. Roosevelt, appointed the Sub-Commission to prepare a draft human rights project. See Z. Resich, op.cit., p. 37; J. Machowski, Prawa człowieka, Wydawnictwo Książka i Wiedza, Warszawa 1968, p. 45.

${ }^{53}$ Cf. General Assembly resolution 217 A (III) adopted in Paris on 10 December 1948; the original text of the Declaration available on: www.ohchr.org (access: 1.6.2017).

${ }^{54}$ ECOSOC Resolution VII/151 of 26 Aug 1948. 
The General Assembly voted on the Declaration on 10 December 1948, announcing it "a common standard to be achieved by all peoples and all nations". In this way, the Universal Declaration of Human Rights (the Declaration/UDHR) was adopted in an exceptionally short time ${ }^{55} .48$ Members voted for it, with 0 votes against and 8 abstained. In the statement after the vote the President of the General Assembly expressed that its acceptance

„by a big majority without any direct opposition was a remarkable achievement (...) it was a step forward in a great evolutionary process. It was the first occasion on which the organized community of nations had made a declaration of human rights and fundamental freedoms. That document was backed by the authority of the body of opinion of the United Nations as a whole and millions of people, men, women and children all over the world, would turn to it for help, guidance and inspiration" 56 .

The Declaration was formulated according to the UN Charter, confirming that "the Member States, in cooperation with the UN, have pledge to ensure universal respect for human rights and fundamental freedoms" ${ }^{\prime 57}$. This reflects the spirit of the Charter by specifying what was already included in the Charter as one of the main purposes of the $\mathrm{UN}^{58}$. The Declaration also develops the provisions of the Charter and defines the substantive content of human rights ${ }^{59}$. However, while working on the Declaration, all efforts were made to maintain a compromise in the sphere of ideology, which found expression in the omission of the philosophical and theoretical justification of human rights, and thus the identification of their non-normative sources. This pragmatism was necessary in this case since, as described by Jacques Maritain:

"It is possible, though certainly not easy, to establish the various rights that a person has in his or her personal and social existence. It would be in vain, ho-

55 Also noted by Olivier De Schutter. The Commission on Human Rights, responsible for preparing the text of the Declaration, adopted it already at its third session held between 24 May to 18 June 1948 - 0. De Schutter, op.cit., p. 15.

${ }^{56}$ See United Nations Action in the Field of Human Rights, New York, UN, doc. ST/HR/2/Rev.1, 1980 and Rev.2, 1982, item. 10.

${ }^{57}$ Cf. Sec. 6 of the Preamble to the UDHR.

58 Cf. Remarks regarding Art. 1(2) and (3) of the UN Charter

${ }^{59}$ Cf. P. N. Drost, Human Rights as Legal Rights, Leyden 1965, p. 33. 
$\because: \because:$ E. H. Morawska, The constitutive instruments...

wever, to seek for them a universally accepted rationale. Striving for it would expose us to the risk of arbitrary dogmatism or stigmatization among the invincible differences" ${ }^{\prime \prime 0}$.

With that being said, this was not an empty compromise as it brought about a document that contains „a wealth of values and ideas” and, as such, is a synthesis of the various traditions, values and needs, many of which had never before been expressed in the language of law ${ }^{61}$. Paul Gordon Lauren is right when he writes that the idea of human rights has a long and rich history, and that its roots do not extend to a specific single geographic region, country, age, or even to a particular form of government or the legal system. Over the centuries, this idea has stemmed from many places, societies, religious and secular traditions, culture ${ }^{62}$. Furthermore, the lack of a doctrinal justification that would be acceptable to all the "United Nations" at the same time does not mean that the human rights listed in the UDHR were completely devoid of justification. It seems the justification was, simply, human being ${ }^{63}$.

${ }^{60}$ As noted by Jacques Maritain „At one of the meetings of the French National Committee of UNESCO, the representatives of opposing ideologies came to an agreement on a preliminary list of rights. Yes, they replied, we agree, provided that we are not asked: why. Why reopens the discussion" - J. Maritain, Człowiek i państwo, Wydawnictwo Znak, Kraków 1993, pp. 83-84.

${ }^{61}$ Cf. remarks by Wiktor Osiatyński, who in the context of the UDHR points to a broad coalition of Christians, Marxists, Socialists and Social Democrats, backed up by American New Deal supporters, as well as think tanks and intellectuals - W. Osiatyński, op.cit., pp. 54-57.

62 P. G. Lauren, The foundation of justice and human rights in early legal texts and thoughts, [in:] D. Shelton (ed.), The Oxford Handbook of International Human Rights Law, Oxford University Press, Oxford 2013, p. 163. Similarly stated by Roman Kuźniar, who says that „The development of the concept of human rights has been discontinuous. Different themes appeared in different eras. Characteristic for other areas of social thought, the phenomenon of accumulation of knowledge in the sphere of human rights did not occur. Hence, the road corresponding to other areas of law - i.e. from idealization, through positivisation, to implementation - In the case of human rights was exceptionally long and complex" - R. Kuźniar, Prawa człowieka: prawo, instytucje, stosunki międzynarodowe, Wydawnictwo Naukowe "Scholar". Warszawa 2008, p. 19.

${ }^{63}$ Cf. M. Piechowiak, Problemy aksjologicznej legitymizacji uniwersalnego systemu ochrony praw człowieka, [in:] E. Karska (ed.), op.cit., p. 100. 
In the light of the provisions of the Declaration, a person is entitled to enjoy the human civil and political rights ${ }^{64}$, as well as the economic, social and cultural rights ${ }^{65}$. Thus, the Declaration is not only the first universal international document containing the catalog of human rights and freedoms, but it is also the first such complex document, as acknowledged already in the UN Charter by its integral approach to human rights and freedoms ${ }^{66}$. On the other hand, this openness to human rights and freedoms was significantly limited ${ }^{67}$ as the catalog in question derived principally from the provisions of the then constitutions of the UN Member States ${ }^{68}$. It was therefore drafted so as to correspond to the constitutional guarantees of that time and as such was to be regarded as expressing the common principles of all the national laws of the Member States of the United Nations. As Humphrey reports

"[the draft project] may have not included all possible rights, (...) but it contained the political and civil rights of the first generation that could be found in the revolutionary declarations of Great Britain, France and the United States of the 17th and 18th century. (...) It also contained second-generation economic and social rights which could be found in the constitutions of the late $19^{\text {th }}$ and early $20^{\text {th }}$ century, such as those of Sweden, Norway, the Soviet Union and some Latin American countries (...) Each draft of the article was endowed with a comprehensive annotation detailing the relationship with the [human] rights documents that were then binding for the UN Member States, already [then] in the number of fifty-five and counting" 69 .

${ }^{64}$ Cf. Art. 3 - 21 of the Declaration.

65 Cf. Art. 22 - 27 of the Declaration. See also A. Michalska, Podstawowe prawa człowieka w prawie wewnętrznym a Pakty Praw Człowieka, Wydawnictwo Prawnicze, Warszawa 1976, p. 173 et seq.

${ }^{66}$ Cf. T. Jasudowicz, Zasady ogólne prawa międzynarodowego praw człowieka, [in:] B. Gronowska, T. Jasudowicz, M. Balcerzak, M. Lubiszewski, R. Mizerski (eds.), op.cit., pp. 181-183.

${ }^{67}$ Cf. S. Greer, The European Convention on Human Rights: Achievements, Problems and Prospects, Cambridge University Press, Cambridge 2006, p. 10; Also M. A. Glendon, Knowing the Universal Declaration of Human Rights, "Notre Dame Law Review" 73 (1998), p. 1176.

68 0. De Schutter, op.cit., p. 31; when the Declaration was being drafted, only 58 states formed part of the United Nations.

${ }_{69}$ As cited in M. A. Glendon, A World Made New: Eleanor Roosevelt and the Universal Declaration of Human Rights, Randon Hause Trade Paperback, New York 2001, pp. 57-58. 
$\because: \because:$ E. H. Morawska, The constitutive instruments...

Additionally, the Declaration was not intended to establish a law that would bind the Member States, but rather to indicate an ideal to which "every individual and every social body (...) should aspire"70. It was therefore not prepared to impose legally binding obligations on the Member States. This was clearly confirmed by the chair of the Commission on Human Rights, Eleanor Roosevelt, who noted that:

"In giving our approval to the declaration today, it is a primary importance that we keep clearly in mind the basic character of the document. It is not a treaty; it is not an international agreement. It is not and does not purport to be a statement of law or legal obligation. It is a declaration of basic principles of human rights and freedoms to be stamped with approval of the General Assembly by formal vote of its members and to serve as a common standard of achievement for all peoples of all nations"71.

Consequently, the Member States decided not to set up a mechanism for monitoring compliance with the obligations arising from it ${ }^{72}$. The "strength" of impact of the Declaration on the UN Member States was therefore significantly limited ${ }^{73}$. Hence, it is justified to recognize the concerns of Harold J. Laski that warn against the Universal Declaration becoming the next Brigand-Kellogg Pact ${ }^{74}$, "introduced with the enthusiasm second only to the disregard of its signatories"75.

70 See. The Preamble to the UDHR.

71 E. Roosvelt, Chairman of the Human Rights Commission, Statement to the General Assembly (9 Dec.1948), [in:] Department of Sate Bulletin (19 Dec. 1948), p. 751.

${ }^{72}$ See J. P. Humphrey, The Right of Petition in the United Nations "Human Rights Journal" 4 (1971), p. 463; H. Lauterpacht, The International Bill of the Rights of the Man, Columbia University Press, New York 1945 (reprinted in 1968), pp. 221-251; criticism of the UN to this lack: pp. 286-292, p. 337, pp. 375-377.

${ }^{73}$ A.W.B. Simpson, Hersch Lauterpacht and the Genesis of the Age of Human Rights, "Law Quarterly Review" (2004), Vol. 120, pp. 74-79.

${ }^{74} \mathrm{Cf}$. General treaty for renunciation of war as an instrument of national policy, which was signed in Paris, in 1928; States parties renounced war as a national policy instrument. Finally, 62 countries have been parties to this Pact, including Japan and Italy. Nevertheless, in practice it did not fulfill its main purpose, because the states did not abandon the war: in 1931 Japan invaded Manchuria and in 1935 Italy occupied Ethiopia.

75 Cited after: E. H. Carr, J. Maritain, Human rights: comments and interpretations; a symposium edited by UNESCO, Imprint A, Wingate, London 1949, pp. 85-86. 
These circumstances contributed to the emergence of serious controversy over the legal nature of the Declaration ${ }^{76}$. Once could point to opinions according to which the UDHR could not be considered a legally binding instrument. That view was shared, for example, by Joseph Gabriel Starke, who believed "the Declaration could not and did not seek to be more than a manifesto, a statement of ideals, a pioneering instrument"77. Consequently, "the Declaration is not a legally binding instrument, either directly or indirectly"78. Moses Moskowitz expressed it similarly, emphasizing however that it was "the first human rights manifesto ever to emerge from discussion at the international conference table"79. Zbigniew Resich, meanwhile, wrote in 1981 that:

"there is a consistent view in the literature that the Declaration is only of moral significance, given it is not an international agreement; it has not been either signed or ratified. Nor can it be considered a genuine interpretation of the provisions of the Charter on human rights, or a codification of the universally accepted juridical principles professed by civilized nations" 80 .

In view of the research conducted, it appears that Resich's position may be considered as singular. What is more, the doctrine recognizes a specific attempt - contrary to the explicit intent of the authors of the UDHR - to justify the legally binding character of the Declaration ${ }^{81}$. It is important in this respect to factor in time and common practice. And so, in the opinion of Louis B. Sohn:

${ }^{76}$ Cf. S. Greer, op.cit., p. 10; J. Symonides, Powszechna Deklaracja Praw Człowieka (po 60 latach od jej przyjęcia), „Państwo i Prawo” (2008), Issue 12, pp. 3-16.

77 J. G. Starke, Introduction to International Law, Butterworths, Oxford-Waltham-Massachusetts 1989 [10 ${ }^{\text {th }}$ ed.], p. 364.

${ }^{78}$ L. Oppenheim, International Law, H. Lauterpacht (ed.), Vol. I, Longman, London 1956, p. 740.

${ }^{79}$ M. Moskowitz, The politics and Dynamics of Human Rights, New York 1968, p. 102.

80 Z. Resich, op.cit., p. 40.

81 Moreover, already in 1968, the International Conference on Human Rights, held in Tehran from 22 April to 13 May 1968, pointed out that "the Universal Declaration of Human Rights expresses the common understanding by peoples of the world of the inalienable and inviolable rights of all human family members and constitutes a commitment for all members of the international community". See Proclamation of Tehran, Final Act of the International Conference on Human Rights) of 13 May 1968, Tehran, U.N. Doc. A/CONF.32/41 (1968), § 2. 
$\because: \because:$ E. H. Morawska, The constitutive instruments...

„Today the declaration not only constitutes an authoritative interpretation of the Charter obligations but also a binding instrument in its own right, representing the consensus of the international community on the human rights which each of its members must respect, promote and observe" ${ }^{\prime 2}$.

Humphrey shared the same view, stating the following:

„in the more than a quarter of a century since its adoption (...) The Declaration has been invoked so many times both within and without the United Nations that lawyers now are saying that, whatever the intention of its authors may have been, the Declaration is now part of the customary law of nations and therefore is binding on all states. The Declaration has become what some nations wished it to be in 1948: The universally accepted interpretation and definition of the human rights left undefined by the Charter" ${ }^{\prime \prime 3}$.

The above thought is elaborated on by Buergenthal who rightly points out to the process of transforming the Declaration from a non-binding recommendation into a normative instrument ${ }^{84}$. According to Richard B. Lillich, it is now possible to argue convincingly that an important part of the Declaration, which was originally not intended to impose international legal obligations, has become a part of international customary law that has bound all states over the past years ${ }^{85}$. What is more, he does not doubt that many of the human rights listed in the Declaration not only reflect customary international law but also belong to jus $\operatorname{cogens} s^{86}$. On the other hand, the

82 L. B. Sohn, The Human Rights Law of the Charter, "Texsas International Law Journal" 12 (1977), p. 133; idem, The New International Law Protection of the Rights of Individuals rather than States "American University Law Review" 32 (1982-1983), stating that the Declaration "has become a basic component of international customary law, binding on all states, not only members of the UN". See also M. Mc Doughal, H. Lasswell, L. Chen, Human Rights and World Public Order: The Basic Policies of an International Law of Human Dignity, Yale University Press, New Haven, 1980, p. 274.

${ }^{83}$ J.P. Humphrey, The International Bill of Rights, p. 529. Similarly, idem, The Universal Declaration of Human Rights: Its History, Impact and Judicial Character, [in:] B. G. Ramcharan (ed.), Human Rights: Thirty Years After the Universal Declaration, Martinus Nijhoff, Hague 1979, p. 33.

${ }^{84}$ T. Buergenthal, op.cit., p. 60.

85 R. B. Lillich, Global Protection of Human Rights, [in:] T. Merton (ed.), Human Rights in International Law: Legal and Policy Issues, Oxford University Press, Oxford 1984, p. 116.

${ }^{86}$ Ibidem, p. 118. 
I.C.J. judge Muhammad Ammoun, in a separate opinion to the ruling in $\mathrm{Na}$ mibia, expressed the view that:

"Although the affirmations of the Declaration are not binding qua international convention within the meaning of Art. 38, paragraph 1(a) of the Statute of the Court, they can bind States on the basis of custom within the meaning of paragraph 1(b) of the same Article, whether because they constituted a codification of customary law (...) or because they have acquired the force of custom through a general practice accepted as law, in the word of Art. 38, paragraph 1(b), of the Statue" ${ }^{\prime 7}$.

Then again, the I.C.J. itself has yet to state, expressis verbis, that the Declaration, as such, taking into account all its articles, should be regarded as customary international law, despite the fact the Hague repeatedly cited its provisions, though always with reference to a specific law and not always presenting the Declaration as its source. For instance, with reference to the ban on arrest or detention on the basis of arbitrary decisions ${ }^{88}$, the I.C.J ruled that wrongfully to deprive human beings of their freedom and to subject them to physical constraint in conditions of hardship is in itself manifestly incompatible with the principles of the Charter of the United Nations, as well as with the fundamental principles enunciated in the Universal Declaration of Human Rights ${ }^{89}$.

3. Irrespective of these controversies, it is difficult to deny the crucial role played by the UN Charter and the Declaration in the process of establishing a regime for the international protection of human rights and its fur-

87 Dissenting opinion of judge M. Ammoun to the advisory opinion of the I.C.J. on Legal Consequences for States of the Continued Presence of South Africa in Namibia (South West Africa) notwithstanding Security Council Resolution 276 (1970) of 21 June 1971, item. 76, I.C.J. Reports 1971, p. 16.

${ }^{88}$ See. Art. 9 of the UDHR.

${ }^{89}$ See the I.C.J. ruling in Case Concerning United States Diplomatic and Consular Staff in Tehran. (United States of America v. Iran) of 24 May 1980, item. 91, I.C.J. Reports 1980, p. 3 "Wrongfully to deprive human beings of their freedom and to subject them to physical constraint in conditions of hardship is in itself manifestly incompatible with the principles of the Charter of the United Nations, as well as with the fundamental principles enunciated in the Universal Declaration of Human Rights". 
$\because: \because:$ E. H. Morawska, The constitutive instruments...

ther development ${ }^{90}$. These documents have laid the foundations for many legally binding instruments, including both international human rights pacts and regional human rights treaties ${ }^{91}$. Already in 1948, the 9th International Conference of American States was convened in Bogota, and the result of its work was, among others, the adoption of the Charter of the Organization of American States ${ }^{92}$ and the adoption of the American Declaration on the Rights and Duties of $\mathrm{Man}^{93}$. These documents were adopted in April 1948, which means the declaration in question was the first international human rights instrument of general application ${ }^{94}$.

The Universal Declaration of Human Rights also inspired the activities in Europe ${ }^{95}$ that resulted in the founding of the Council of Europe (CoE) ${ }^{96}$, whose statute explicitly stated that it was open only to the democratic states that adopted the principle of the rule of law on the basis of their constitution

${ }^{90}$ For more cf. R. Wieruszewski, ONZ-owski system ochrony praw człowieka, [in:] B. Banaszak (ed.), System ochrony praw człowieka, Wolters Kluwer Polska, Kraków 2005, pp. 60-61.

91 E. Schwelb, The Influence of the Universal Declaration of Human Rights on International and National Law, "American Society of International Law Proceedings" 53 (1959), p. 217.

92 The OAS Charter was adopted on 30 April 1948 and became binding on 13 December 1951; the text of the Charter is available online: https://treaties.un.org/doc/ Publication/UNTS/Volume\%20119/volume-119-I-1609-English.pdf (access: 4.6.2017).

93 The text of this Declaration is available online: http://www.cidh.oas.org/Basicos/English/Basic2.american\%20Declaration.htm (access: 4.6. 2017).

94 Cf. C. McCrudden, Human Dignity and Judicial Interpretation of Human Rights, "European Journal of International Law" 19 (2008), pp. 655-724.

${ }_{95}$ It should be stressed, however, that the work on the European system of human rights protection raised serious concerns. For example, in his memoirs, Pierre-Henri Teitgen pointed out that in opposition to him - the advocate of that system and the establishment of the European Court - was, among others, the French Nobel Peace Prize laureate, participant of the work - within the Commission on Human Rights - on the UDHR, R. Cassin, who "was openly opposed to it because he considered it unlikely that any other regional institution could function effectively without referring to the Universal Declaration of Human Rights" - P. H. Teitgen, Faites entrer le témoin suivant 1940 -1958: de la Résistance à la Ve République, Ouest France, Rennes, 1988, p. 489.

96 The Statute of the CoE was adopted in London on 5 May 1949 (European Treaty Series (ETS) No. 1. 10 European states were parties to it and they were: the Kingdom of Belgium, the Kingdom of Denmark, the French Republic, the Irish Republic, the Italian Republic, the Grand Duchy of Luxembourg, the Kingdom of the Netherlands, the Kingdom of Norway, the Kingdom of Sweden and the United Kingdom of Great Britain and Northern Ireland; the Statute entered into force on 3 August 1949. 
and the principle of the protection of human rights and fundamental freedoms ${ }^{97}$. As known, one of the most important treaties of the CoE is the Convention for the Protection of Human Rights and Fundamental Freedoms, designed originally as a legally binding instrument of a collective guarantee of human rights and fundamental freedoms ${ }^{98}$, enhanced by a mechanism to ensure that the arising obligations are respected by the states ${ }^{99}$.

In view of the analysis, it seems reasonable in the light of which the UN Charter and the Universal Declaration of Human Rights have sparked a postwar process, to which Louis Henkin refers to as the process of the internationalization of human rights, and therefore "transformation of the ideas of constitutional rights [guaranteed in certain states] into a universal idea", functioning in the sphere of international politics and international law ${ }^{100}$.

It must be emphasized that although the UN Charter has played a constitutive role in the internationalization of human rights, the Universal Declaration of Human Rights is a universal milestone in this process ${ }^{101}$. Its special significance was highlighted in the 1968 Proclamation of Tehran, undertaken at the conclusion of the International Conference on Human Rights

${ }^{97}$ It is necessary to call attention to the provisions of art. Art. 3 and Art. 8 of the Statute of CoE, which are seen as unique in the history of international organizations. Cf. C. Ovey, R.C.A. White, F.G. Jacobs (ed.), op.cit., p. 4.

98 Council of Europe, Preparatory Work on Article 1 of the European Convention on $\mathrm{Hu}$ man Rights, Strasburg 1977, p. 68: http://www.echr.coe.int/library/DIGDOC/Travaux/ ECHRTravaux-ART1-COUR(77)9-EN1290551.PDF, (access: 1.6. 2017).

99 A. Z. Drzemczewski, The Prevention of Human Rights Violations: Monitoring Mechanisms of the Council of Europe, „International Studies in Human Rights” 67 (2001), pp. 158-163; For reference on the following issues see: T. Novitz, Remedies for Violation of Social Rights within the Council of Europe: the Significant Absence of a Court, [in:] C. Klipatrick, T. Novitz, P. Skidmore (eds.), The Future of Remedies in Europe, Oxford University Press, Oxford 2000, pp. 231-251; just as in J. G. Merrills, The Development of International Law by the European Court on Human Rights, Manchester University Press, Manchester 1995, p. 2.

100 See L. Henkin, The Age of Rights, Columbia University Press, New York 1990, pp. 13-20.

101 R. Y. Jennings, A. D. Watts (eds.), Oppenheim's International Law: Volume 1 Peace, Oxford University Press, London 1992, p. 1001; M. M. Whitman, Digest of International Law, Vol. 5, Washington 1965, p. 237; J.P. Humphrey, The Universal Declaration on Human Rights, [in:] B.G. Ramcharan (ed.), Human Rights: Thirty Years after The Universal Declaration, Martinus Nijhoff, The Hague 1979, p. 21. 
$\because: \because:$ E. H. Morawska, The constitutive instruments...

and stating that it constitutes "an obligation for the Members of the international community"102. The Vienna Declaration and Programme of Action, adopted at the 1993 World Conference on Human Rights, in turn, stressed that the Declaration "is the source of inspiration and has been the basis for the United Nations in making advances in standard setting as contained in the existing international human rights instruments"103.

It has been referred to on many occasions, and its importance to international human rights law can hardly be stressed enough.

The article deals with some aspects of the process of the internationalization of human rights. The analysis essentially covers the question of two international documents: the United Nations Charter (UN Charter) and the Universal Declaration of Human Rights (the Declaration). The article underlines that the UN Charter is generally considered a special treaty. Being a treaty that constitutes the UN, it is perceived both as the fundamental anchoring of the obligations of the States in the sphere of international law, and as such is recognized as an international quasiconstitution. Meanwhile, the human rights clauses contained in the UN Charter set the stage in the process of institutionalizing human rights within international law and, consequently, establishing a new branch of international law, i.e. international human rights law.

The greater part of the article is dedicated to the Universal Declaration of $\mathrm{Hu}$ man Rights as a universal milestone in the process of internationalization of human rights. The article refers to debates on its philosophical roots, and above all its legal nature.

The article highlights the evolution of doctrine and international jurisprudence in the latter area. At the same time, it shows a specific search - contrary to the explicit intent of the authors - to justify the legally binding nature of the Declaration.

102 Proclamation of Tehran, Final Act of the International Conference on Human Rights) z 13.05.1968 r., Tehran, U.N. Doc. A/CONF.32/41 (1968), § 2 „The Universal Declaration of Human Rights states a common understanding of the people of the world concerning the inalienable and inviolable rights of all members of the human family and constitutes an obligation for the members of the international community".

103 The Vienna Declaration and Programme of Action, adopted at the World Conference on Human Rights in Vienna, 1993, as cited in R. Kuźniar, op.cit., p. 438. 